Article

\title{
Towards a Sustainable Sun, Sea, and Sand Tourism: The Value of Ocean View and Proximity to the Coast
}

\author{
Gabriela Mendoza-González ${ }^{1,2,3, *(\mathbb{C})}$, M. Luisa Martínez ${ }^{1}$ (1) , Roger Guevara $^{1}$ (i), \\ Octavio Pérez-Maqueo ${ }^{1}$ [D, María Cristina Garza-Lagler ${ }^{2,3}{ }^{\mathbb{B}}$ and Alan Howard ${ }^{4}$ \\ 1 Institute of Ecology, C.A., Carretera Antigua a Coatepec No. 351, El Haya, Xalapa 91500, Mexico; \\ marisa.martinez@inecol.mx (M.L.M.); roger.guevara@inecol.mx (R.G.); octavio.maqueo@inecol.mx (O.P.-M.) \\ 2 CONACYT-Faculty of Sciences, Academic Unit of Yucatan, National Autonomous University of Mexico, \\ Carretera Sierra Papacal Chuburná Puerto Km 5, Sierra Papacal, Yucatan 97302, Mexico; \\ mcristina.garza@gmail.com \\ 3 National Coastal Resilience Laboratory (LANRESC), National Autonomous University of Mexico, Sisal, \\ Yucatan 97302, Mexico \\ 4 Statistical Software Support \& Consulting Services, University of Vermont, Burlington, VT 05405, USA; \\ alan.howard@uvm.edu \\ * Correspondence: gabriela.mendoza@ciencias.unam.mx or gaballito@gmail.com; \\ Tel.: +52-(999)-341-0860 (ext. 7626)
}

Received: 21 December 2017; Accepted: 14 March 2018; Published: 29 March 2018

\begin{abstract}
Coastal tourism is expanding worldwide, mostly owing to the attraction to relevant ecosystem services such as the scenic beauty and recreational activities. The aim of this study was to analyze the value of these, using hedonic analysis by assessing how prices of hotel rooms are related to the scenic view, location, non-ecosystem amenities, and size of the hotels in three touristic areas of Veracruz, México. We found that, besides the size of the hotel and the number of non-ecosystem amenities, room prices increased by $8 \%$ and $57 \%$, depending on the ocean view and accessibility to the beach, respectively. These results help to understand why hotels are built very close to the coastline, despite the high risk of extreme and frequent meteorological events. The unorganized and intense development of the tourist industry may act in contrast to the necessity for conservation of the natural ecosystems, rendering this activity highly unsustainable. The question is how to deal with the dilemma of tourism growth and conservation. We suggest some alternatives that might help with the conservation of natural ecosystems, while maintaining the combined provision of simultaneous coastal ecosystem services such as an aesthetically pleasing view and recreation, as well as additional services such as storm protection.
\end{abstract}

Keywords: hedonic price; coastal landscape; beach proximity; tourism industry; coastal protection; beach and costal dunes

\section{Introduction}

Tourism is one of the most important economic activities worldwide, and its growth and expansion have generated notable economic, social, and cultural benefits that contrast with the considerable impacts it often has on the surrounding natural environment [1,2]. Globally, expenditures by international visitors on accommodation, food and drink, entertainment, and other services and goods reached US $\$ 1260$ billion in 2015, which represents an increase of $4.4 \%$ over 2014 [3]. In particular, the coasts are the most appreciated environment in tropical areas, and consequently, tourism has become a mass phenomenon where every year, millions of people seek relaxation and recreation, preferably at the beach $[4,5]$. For this reason, many touristic developments and associated infrastructure 
are found at or very close to the coast, providing amenities and services that visitors pursue for their own comfort and enjoyment.

Mexico is the ninth most visited country in the world, the second most visited country in the American continent (after the USA), and the number one destination in Latin America [3]. In Mexico, tourism contributes $8.6 \%$ of the national GDP and $45 \%$ of tourists choose the coastal zone as their destination [3]. Touristic activities on the 17 coastal states in Mexico take place with different intensities, although all of them are of great social and economic importance. International tourism is mainly directed to Cancun, Los Cabos, and Puerto Vallarta, while national tourism is concentrated in Acapulco, Veracruz, and Cancun [6].

Indeed, tourism in Mexico (especially sun, sea, and sand tourism) has been considered a national priority since the 1950s $[7,8]$ because of the extensive coastline and abundance of sandy beaches. The policies that have promoted coastal tourism during the last decades have resulted in the creation of major international tourism destinations through the establishment of large hotel groups (mainly international chains) of global relevance, which leads to the arrival of tourists with high purchasing power [7]. Nowadays, nearly $50 \%$ of the hotel rooms in Mexico are in coastal destinations [7], and these trends are probably similar to other countries with a coastline. However, despite the evident socioeconomic benefits, the creation and development of these new coastal urban centers have been mostly disorderly and inappropriate and thus, have affected the structure and functioning of natural ecosystems through the flattening of dunes, elimination of natural vegetation, and draining and pollution of wetlands. The loss of such coastal ecosystems is of great importance, since they function as a habitat for wildlife and offer a variety of ecosystem services, including shoreline protection $[9,10]$. Furthermore, because coastal tourism often relies on high quality environments [11], when coastal ecosystems are lost or degraded, the attraction that interested tourists in the first place is lost. This shows how most current policies aimed at tourism over exploitation can become highly unsustainable.

Why do tourists prefer the coast? The preference of sun, sea, and sand tourism has been analyzed for different locations. On the northern coast of Poland, Jedrzejczak [3] found that coastal tourists chose the coasts for vacationing because of fresh air and recreation activities, and, in a minimum percentage, because of the scenic beauty. In turn, Williams [12] assessed tourist preferences in 5 beaches from the UK, USA, Malta, Turkey, and Spain. The results of this study revealed that among 50 aspects that were analyzed, tourists were mostly interested in water quality, safety, facilities, absence of litter, and scenic beauty. George et al. [13] analyzed the supply and demand of attractions in the Caribbean region and found that tourists preferred warm weather and proximity to the beach. In turn, in a worldwide study, Onofri and Nunes [14] identified two groups of tourists based on their preferences: the first were mainly foreigners with an interest in cultural activities and natural environments, while the second group were national tourists whose preferences were related to the beach and its attributes such as width. More locally, Vargas-Martínez et al. [15] found that international tourists in Cancun, Mexico, were concerned about environmental quality and were willing to pay for environmentally friendly actions. In contrast, a smaller fraction of Mexican tourists was environmentally concerned. From the studies described above, it can be concluded that although the preferences of coastal tourists are very diverse and change between locations and over time, two demands stand out: the recreation activities and the scenic beauty of the coastal landscape. Consequently, it is of relevance to assess how society confers an economic value to these ecosystem services.

In México, Pérez-Verdín et al. [16] found that amongst all the ecosystem services that have been analyzed, the most evaluated service was recreation, followed by water and agriculture resources. Studies of the ecosystem services provided by Mexican coastal dunes are very rare [17]. To our knowledge, to date there is only one published peer-reviewed study in which the value of coastal dune ecosystem services is analyzed [18] and in this case, it was recognized that one of the most valuable ecosystem services was coastal protection. However, while recognition has also been given to the 
importance of the aesthetic value of the sea, beach, and dune landscape, and recreation, these aspects have not been explored in detail.

The hedonic price theory was developed by Rosen [19] and is one of the methods used to assess the aesthetic value of a landscape. This type of analysis is based on the idea that the value of a product depends on its characteristics and attributes, which include its location and surroundings. Hedonic analysis is a widely used method for estimating the value of ecosystem services, such as landscape aesthetics, and the presence of a natural landscape (forest, lake, or beach) [20-24] vs. the poor quality of surroundings that include nuclear plants, garbage dumps, toxic areas, refineries and polluted areas, narrow beaches, and hard engineering structures, among others $[20,25,26]$. Thus, hedonic analysis statistically separates the effect of the intrinsic value of the properties from other factors in the surroundings [20-23]. This methodology can be used on the coasts to help provide an estimate of the willingness of tourists to pay for the aesthetics of the landscape and the potential for recreation [20,27-30].

Although useful, some of the critiques of the hedonic analysis are based on how the data are collected, because in many cases they come from interviews. Thus, the results are subjective because they depend on the perception of the interviewees [31]. Therefore, to avoid this problem, we used the prices of hotel rooms, which are objective and depend on the supply-demand market. A similar approach has been used previously. For example, Vanslembrouch et al. [28] found that landscape characteristics associated with agricultural activities increased the demand for rural tourism and induced an increased willingness to pay for accommodation immersed in natural surroundings. In a coastal setting, Hamilton [20] observed that in Germany, hotel prices were higher on natural beaches, in comparison with developed beaches with dykes and breakwaters. Similarly, in Spain, Rigall-I-Torrent et al. [29] explain that being in front of a beach increased hotel prices by $13 \%$ to $17 \%$, while Rangel-Buitrago et al. [32] and Ergin et al. [33] concluded that scenery was a very important component for beach tourism, driving the economy of many coastal areas on the Caribbean coasts of Colombia as well as Malta, Turkey, and UK, respectively. The same trends have been observed in Mexico, where Lloret et al. [34] used a hedonic analysis in 34 beaches and found that hotel prices increased with sustainable activities such as ecotourism and water quality.

Based on the above, the premise of this study was that proximity of the hotels to the beach and access to an aesthetically pleasing ocean view play an important role in the choices made by tourists as well as in their willingness to pay higher hotel prices. Thus, our objective was to analyze the value of these ecosystem services (aesthetic and recreational) by using the cost of hotel rooms as a measure of tourists' willingness to pay in zones with contrasting touristic infrastructure. We focused our study on the coasts of the state of Veracruz since this is a popular tourist destination [35] where, during the last three decades, human activities have generated rapid land use change, with a $36 \%$ reduction in the original forest cover and an intense erosion on the coast [36].

\section{Methods}

\subsection{Study Area}

The state of Veracruz is located in the central region of the Gulf of Mexico (Figure 1). Its shoreline covers $745 \mathrm{~km}$ and is of great ecological, social, and economic importance at local, regional, and national levels. Nationally, Veracruz is one of the states with the largest area and variety of coastal dunes [6].

The coastal population of the state of Veracruz is relatively high: $20 \%$ of the cities of Veracruz and $27 \%$ of the state population (ca. 1,900,000 inhabitants) live less than $20 \mathrm{~km}$ from the coastline [17]. Tourism is very important in the state of Veracruz and occurs in contrasting settings that range from highly developed cities with amenities and infrastructure to semi-developed areas with more natural surroundings and a lower number of amenities. Based on the above, we compared three contrasting touristic destinations located in the center of the coast of the state of Veracruz (Figure 1). From our three study sites, Boca del Río (in the municipality of Boca del Río) is the area with the largest anthropic 
impact, since it is highly urbanized and presents a very diminished area with natural ecosystems. Forming part of the Veracruz-Boca del Río touristic complex, most of the landscape is urbanized with intense touristic activities and the presence of large hotels, many of which are transnational, with a large variety of services offered. Small remnants of the natural (mangrove and beach) and semi-natural (cultivated pasture) ecosystems still exist (Table 1). The beach at this site is discontinuous along the length of the coastline due to the presence of groins that were constructed in recent decades; the sediment that supplies the beach accumulates to one side of these protective structures while being lost from the other because of the disruption they cause to the natural sedimentary dynamics $[6,33]$. The beaches present in this zone are narrow and, for some of the hotels studied, the sea breaks directly on to the hotel with no beachfront.

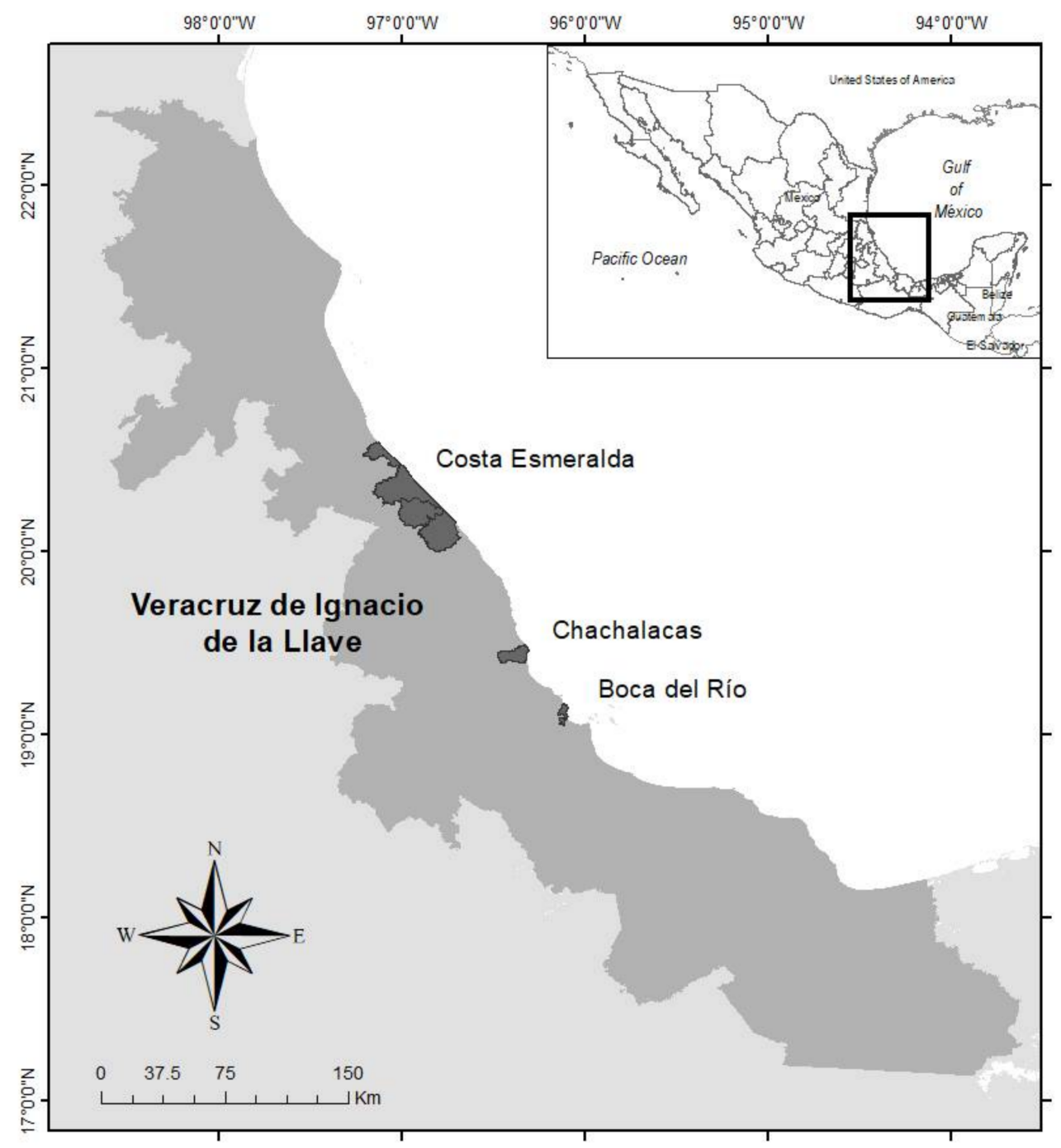

Figure 1. Location of the study sites in the state of Veracruz.

Costa Esmeralda is a touristic corridor that comprises various municipalities (Tecolutla, San Rafael, and Nautla) where hotels are less densely distributed. A high percentage of semi-natural ecosystems such as croplands and pastures remains and it accounts for $81 \%$ of the landscape along with some remnants of natural ecosystems such as mangrove and extensive beaches (Table 1). The urban area occupies a low percentage of the study area, although there has been a recent trend towards accelerated development driven by the tourist industry [17]. The beach of Costa Esmeralda is continuous and, in some areas, very wide (100-150 m). 
Finally, Chachalacas is a touristic zone developed in the municipality of Úrsulo Galván. Here, the area of natural and semi-natural ecosystems, as well as cultivated zones, is much greater. Urban growth in this site has taken place parallel to the coastline, mostly with the development of hotels and houses. The study area comprises a landscape with mosaics differentiated by agricultural and livestock production zones, an extensive coastal dune system, pastures, beach, urban zones, fragments of tropical forest, and coastal scrubland and wetlands in the lower parts of the dunes (Table 1). Here, the beach is continuous and, until 2007, presented strong erosion since the waves broke directly onto the restaurants constructed on the beach. During 2009 and 2010, two breakwaters were constructed and the beach has grown, while it has generated severe erosion further down-drift. One tourist attraction that has been strongly developed in the region is the use of four-wheeled motorcycles on the coastal dunes as a recreational activity [37].

Table 1. Percentage of different and use cover in the three study sites within a $2.5-\mathrm{km}$-wide band stretching inland from the shoreline. Numbers in parentheses denote the area in hectares (data modified from Mendoza-González et al. [18]).

\begin{tabular}{cccc}
\hline Attribute & Boca del Río & Costa Esmeralda & Chachalacas \\
\hline Forest & & & $1(26)$ \\
Cropland & & $53(1642)$ & $19(492)$ \\
Dunes & & & $22(581)$ \\
Floodplains & & & $1(26)$ \\
Mangroves & $9(213)$ & $9(278)$ & \\
Scrubland & & $2(53)$ & $24(632)$ \\
Grassland & $6(140)$ & $28(870)$ & $27(696)$ \\
Beach & $2(30)$ & $1(51)$ & $1(27)$ \\
Urban & $83(1901)$ & $7(220)$ & $5(142)$ \\
\hline
\end{tabular}

\subsection{Hedonic Analysis}

The importance of the aesthetic and recreational ecosystem services (specifically access to an ocean view and proximity to the beach) was analyzed in the hotels located within a $300 \mathrm{~m}$ strip running perpendicular to the coastline. This distance was considered to be the range within which tourists had the greatest opportunity to directly access the coastal landscape and the recreational activities of the beach. Thus, in this strip, we quantified the number of hotels with (and without) an ocean view and direct (or indirect) access to the beach. When performing our survey, we georeferenced the location of each hotel, and thus, identified the accessibility to an ocean view or not. We also observed if the sampled hotels had a direct access to the beach or if access required moving across communication routes (streets or roads). Hotels in which tourists did not need to walk across a road were considered as "close to the beach" while hotels where it was necessary to walk across a street or road were considered as "far from the beach".

In each hotel, we interviewed hotel personnel and thus gathered the average cost of single and double rooms (see questionnaire in Appendix A). For this purpose, structured questionnaires were designed [38-41] and applied in the reception areas of the hotels during the high season of July 2007 to avoid a seasonal effect on the prices. Finally, in order to ensure that the attributes that give economic value to the landscape aesthetics and recreation on the coast only depend on ecosystem factors, analysis of the hedonic prices was fitted to all the additional factors related to the hotel room prices, which included non-ecosystem elements (hereafter referred to as non-ecosystem amenities).

We made a significant effort to assess as many hotels as possible, and thus, we sampled all the hotels we found in each location, focusing on those that were located at the beach or across the closest road, parallel to the shoreline. Because of differences between the locations (from more urbanized in Boca del Río, to least urbanized in Chachalacas), the number of hotels differed between locations: in Boca del Río we had a total of 16, in Chachalacas 26, and in Costa Esmeralda 50. In the latter case, because Costa Esmeralda is a touristic corridor, we included different beaches: 
La Guadalupe, Ricardo Flores Magón, La Vigueta, Playa Oriente, Monte Gordo, Casitas, and Maracaibo. Because we did not compare between locations, we considered that the differences in hotel density did not represent a problem in terms of our goals.

Hotel prices were recorded in August 2007 and converted to average January-April 2016 prices (due to the volatility of exchange rates during the last months) with a cumulative inflation rate from 2007 to 2016 of $40.96 \%$ using the calculator provided by INEGI [42]. The prices obtained were readjusted to USD/2016, with an exchange rate of 17.85 according to the Banco de Mexico (MXN-USD) [43].

\subsection{Data Analysis}

We used a regression tree model to identify variables driving hotel prices in each location. This model included ecosystem and non-ecosystem characteristics (ecosystem: landscape, location; non-ecosystem: site, total number of rooms, and amenities). Also, because the actual number of amenities was different among the studied sites, we used a second tree model based on the cost of hotel rooms weighted by the number of amenities at each hotel. In this way, we have a standardized, readily compared estimate of cost across dissimilar sites. In these analyses, ocean view (view and no view) and proximity (near and far) had two levels. Because a single classification tree may be misleading and idiosyncratic, we used the approach of forest of trees in which each of the 1000 trees computed was computed on a random subset $(80 \%)$ of the total database. This was modeled in a Language and Environment for Statistical Computing, the R software (3.3.1, by R Development Core Team, R Foundation for Statistical computing, Vienna, Austria, 2013).

Once we found the most relevant variables, we performed a general linear regression model to test the relevance of environmental variables: proximity to the beach and access to an ocean view. The response variable was price per room, and the explanatory variables included the number of non-ecosystem amenities offered by each hotel and ecosystem services (recreation and scenic view). These data were grouped as numerical and categorical variables (see above) (Table 2). Services per hotel were defined as the total number of non-ecosystem amenities as a proxy of hotel classification, because in Mexico, there is not yet a standardized criterion that classifies the different types of hotel (boutique, bungalow, rest houses, etc.) according to the quality of the services that the guests receive, but rather based on the number of amenities [44]. Because of the high heterogeneity between the sizes of the hotels at the study sites with costly small boutiques and large international hotels, we explored if the number of rooms explained the cost of the room.

Table 2. Response and explanatory variables used to conduct the hedonic analysis. Ecosystem variables are shown in bold type. (Number of observations: Boca del Río 16, Costa Esmeralda 26, Chachalacas 52).

\begin{tabular}{ll}
\hline \multicolumn{1}{c}{ VARIABLES } & \multicolumn{1}{c}{ CHARACTERISTICS } \\
\hline $\begin{array}{l}\text { Price per room (mean value of single and double } \\
\text { rooms, response variable) }\end{array}$ & $\begin{array}{l}\text { Price (USD/2016) of each one of the types of rooms present in } \\
\text { all the hotels }\end{array}$ \\
\hline $\begin{array}{l}\text { With and without an ocean view } \\
\text { (ecosystem service, binary explanatory variable) }\end{array}$ & $\begin{array}{l}\text { Access to an aesthetically pleasing view of the landscape of the } \\
\text { beach and the ocean from the hotel room (values of 0 and 1) }\end{array}$ \\
\hline $\begin{array}{l}\text { Hotel location. Presence of beach in front of the hotel } \\
\text { (ecosystem service, binary explanatory variable) }\end{array}$ & $\begin{array}{l}\text { Ability to access the beach without a requirement to traverse the } \\
\text { road (values of 0 and 1) }\end{array}$ \\
\hline $\begin{array}{l}\text { Services per hotel } \\
\text { (non-ecosystem amenities, explanatory numerical } \\
\text { variable, total number of non-ecosystem amenities } \\
\text { was quantified from 1 to 12) }\end{array}$ & $\begin{array}{l}\text { Single swimming pool, air conditioning, restaurant, several } \\
\text { swimming pools, conference room, gymnasium, bar, spa, } \\
\text { camping, eco-touristic service, gardens }\end{array}$ \\
\hline $\begin{array}{l}\text { Total number of rooms (non-ecosystem service, } \\
\text { explanatory numerical variable) }\end{array}$ & Number of rooms per hotel \\
\hline
\end{tabular}

To determine the value associated with the ecosystem service of landscape aesthetics and recreation, comparisons were made between the prices of hotel rooms with and without an ocean view, using a general linear model (GLM). In the same way, an analysis was conducted of the value of hotels 
that, by their location, were close to or distant from the beach. The calculations were conducted with the reciprocal since the models used were GLM with GAMMA error and INVERSE link function.

\section{Results}

Proximity to the beach and accessibility to an ocean view varied between the hotels in our study sites. In Boca del Río, $62 \%$ of the hotels were located in front of the ocean, i.e., they had direct access to the beach, and $75 \%$ had rooms with an ocean view. In Costa Esmeralda, these percentages were 58\% and $48 \%$, respectively, and in Chachalacas, only $27 \%$ of the hotels were located in front of the beach, but $73 \%$ had an ocean view.

The most expensive hotels were found in Boca del Río, although lower-priced hotels were also found in this site (Figure 2). In this zone, most of the hotels offered a wide variety of services to the tourists and had a very high average number of rooms per hotel (102). In contrast, lower hotel prices were found in Costa Esmeralda and Chachalacas, with only three and two price categories (respectively), because the variety of hotels in these zones was more homogeneous and the amenities offered to the guests were reduced. The average number of rooms per hotel was 20 in Costa Esmeralda and 15 in Chachalacas because hotels were generally small (Figure 2).

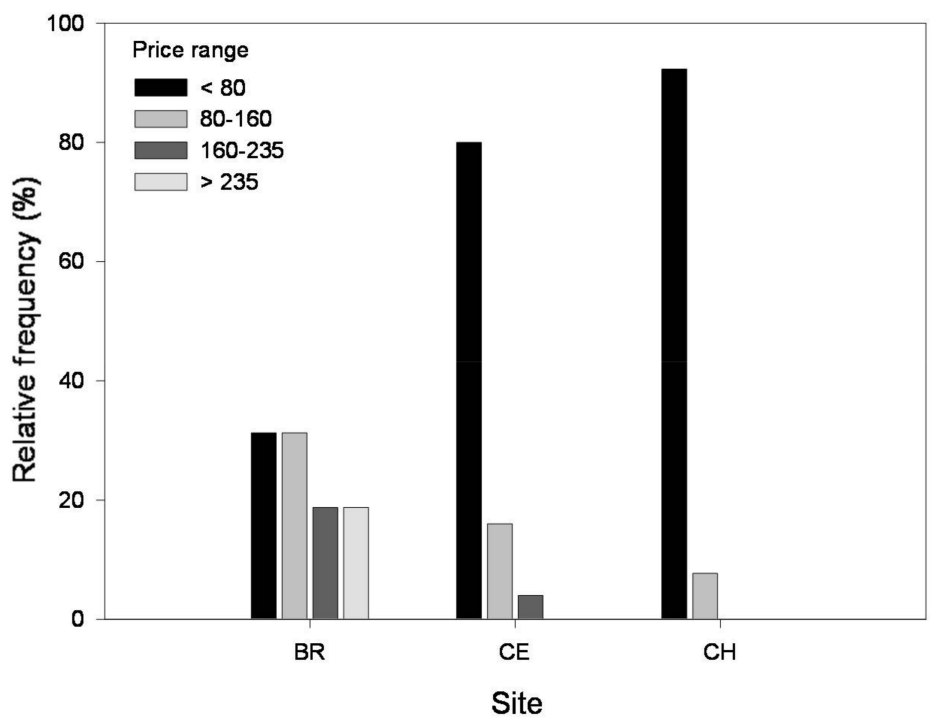

Figure 2. Frequency of different price intervals (USD/2016) in the three study sites. (BR) Boca del Río, (CE) Costa Esmeralda, (CH) Chachalacas.

The tree classification models (Figure 3) explained an average of $93 \%$ of the total deviance in the mean cost of a room (Figure 3a), and revealed that the number of amenities was the variable most widely correlated with the average cost of a room. A room in hotels with less than five amenities (bar A-\$34.4 USD) was, on average, 53\% cheaper than a room in hotels offering between five and six amenities (bar B - \$72.9 USD). In hotels with less than seven amenities (Figure 3a, left side of the tree chart), a room ( $\$ 45.4 \mathrm{USD}$ ) cost on average $69.4 \%$ less than in hotels with seven or more amenities (\$148.7 USD, Figure 3a, right side of the tree chart). Among the hotels with seven or more amenities, the cost of a room was defined by the size of the hotel. In the largest hotels, with an average of 170 rooms (bar D-\$222.9 USD), the mean cost of a room was 96\% higher than in smaller hotels with an average of 47 rooms (bar C-\$114.5 USD). The analyses of hotel prices that excluded number of amenities (Figure 3b) showed that the hotels located in Boca del Río differed significantly from those grouped in Costa Esmeralda and Chachalacas. The first group comprises hotels located in Boca del Río (Figure 3b, right side of the tree chart), where an increase of \$18.8 USD/2016 (bar D) was found, which was associated to non-ecosystem amenities. In the second group (first node on the left part of the 
tree chart), in which coincide hotels from Costa Esmeralda and Chachalacas, the location of the hotel was used to distinguish between those close to and those distant from the beach. For those that were distant, the cost per ecosystem amenity was \$11 USD/2016 (bar A). The groups of hotels that were near the beach were further subdivided, this time as a function of the presence or absence of an ocean view (second node on the right side of the tree chart). This showed that hotel prices were higher when rooms had an ocean view and were near the beach, which resulted in an increment of non-ecosystem amenity of $\$ 17.6$ USD/2016 (bar B). This contrasts with those with no ocean view, where the increased cost due to non-ecosystem amenities was $\$ 11.4$ USD/2016 (bar C). In brief, this analysis shows that: (a) hotel prices are determined, mostly, by the investment in infrastructure, such as amenities and number of rooms; (b) mean hotel prices are higher in Boca del Rio; however, (c) prices in hotels in Chachalacas and Costa Esmeralda can be as high as those in Boca del Río when they are located at the beach and have an ocean view (Figure 3b, bar B).

Overall, our analysis revealed that there were significant differences between study sites in terms of mean cost per room $\left(X^{2}=88.3\right.$, d.f. $\left.=2, p<0.001\right)$. The most expensive zone was Boca del Río, which was 1.54 times more expensive than Costa Esmeralda $(t=6.1$, d.f. $=86, p<0.001)$ and 1.97 times more expensive than Chachalacas ( $t=6.1$, d.f. $=86, p<0.001$ ). No significant difference was found between Costa Esmeralda and Chachalacas $(t=1.2$, d.f. $=86, p=0.231)$. In addition, average prices per room in each of the three sites increased significantly when the hotels were near the shoreline $\left(X^{2}=53.0, d . f=3\right.$, $p<0.001)$ : Costa Esmeralda $(t=2.5$, d.f. $=86, p=0.013)$, Boca del Río $(t=4.9$, d.f. $=86, p<0.001)$ and Chachalacas ( $\mathrm{t}=3.4$, d.f. $=86, p<0.001)$.

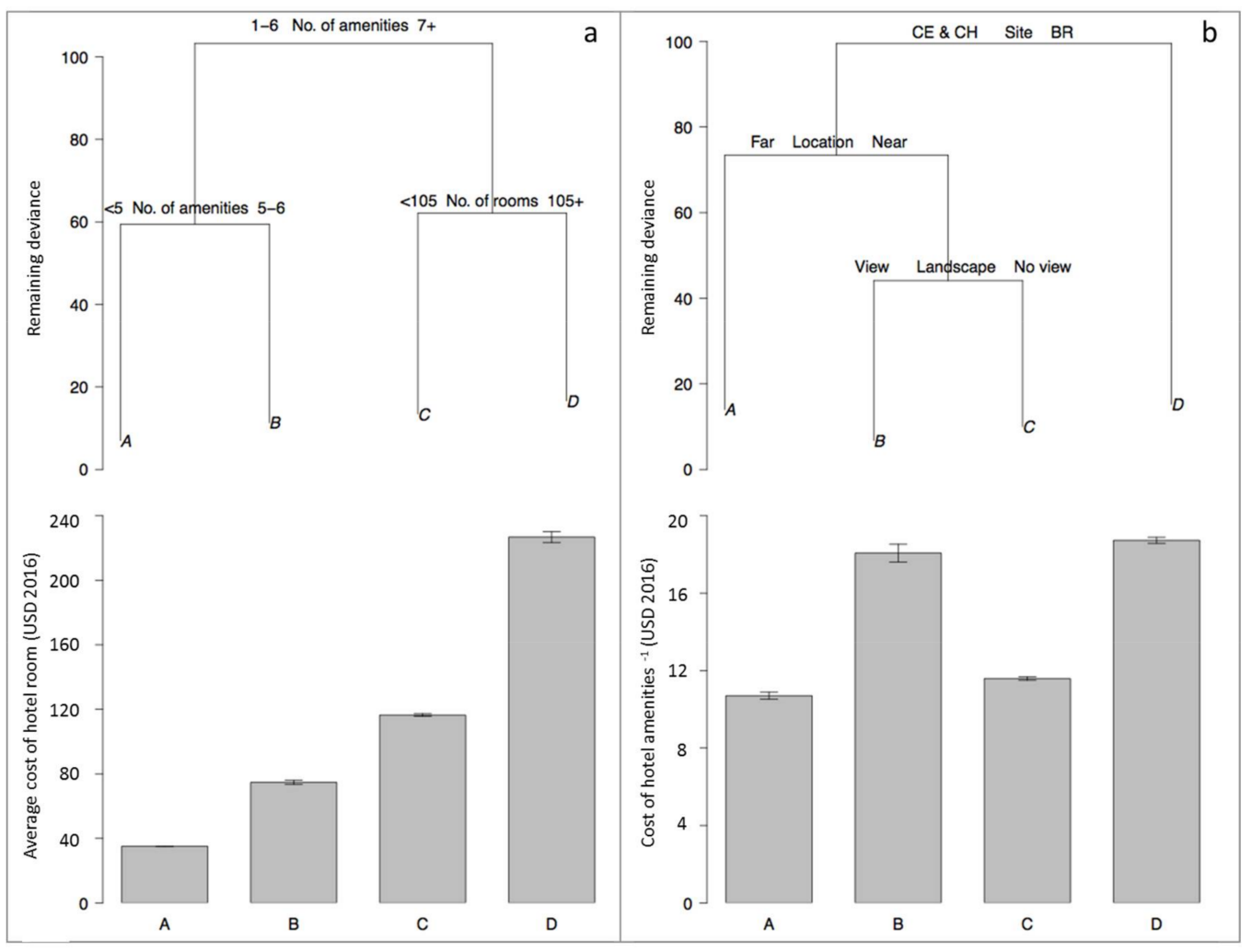

Figure 3. Tree classification model. (a) Consensus tree of a forest of trees analysis fitted on the average cost of hotel room as a function of site, landscape, location, total number of rooms, and number of amenities; (b) Consensus tree of a forest of trees analysis fitted to the cost per amenity as a function of site, landscape, and location. Sites included Boca del Río (BR), Costa Esmeralda (CE), and Chachalacas $(\mathrm{CH})$. In both cases, the bars in the bottom of the panel represent the mean value \pm standard error of the response variable for each of the terminal nodes (A-D) of the corresponding consensus tree. 
Figure 4a shows that the prices of rooms in hotels closer to the beach were significantly higher than those located at a distance, in all three sites. Following the same trends, we found that in the three study sites, hotels with access to an ocean view had higher prices than those that did not have the benefit of this ecosystem service; however, only in Costa Esmeralda were these differences statistically significant (Figure $4 b$ ).
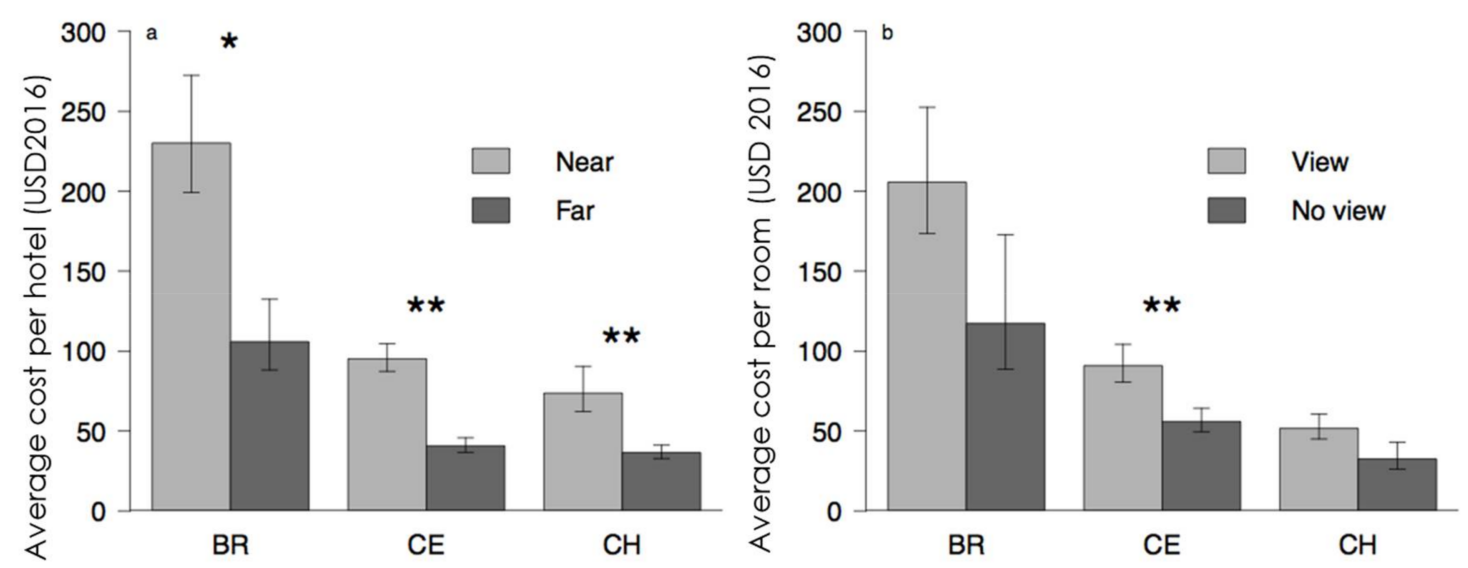

Figure 4. Mean cost per room associated with (a) proximity to the beach, and (b) access to an ocean view. (BR) Boca del Río, (CE) Costa Esmeralda, (CH) Chachalacas. ${ }^{*} p \leq 0.05$ and ${ }^{* *} p \leq 0.01$.

\section{Discussion}

In general, we observed that hotel prices depend on several variables. First, the location of the hotels showed that the costs per room from the most urbanized site (Boca del Río) were significantly higher than in the more rural and less developed settings. Although our design did not consider the comparison between urban and non-urban areas, our results coincide with the findings of Jędrzejczak [4] and Rigall-I-Torrent et al. [29], who observed higher hotel prices in urbanized beaches in Poland and Spain, respectively. In Spain, for example, Rigall-I-Torrent et al. [29] concluded that this is probably related to additional benefits and commodities that are offered by the urban areas. Indeed, in addition to our study, it would be interesting to assess the differences between hotels in urban and suburban areas within the same location. This would facilitate the comparisons within the same location for hotels with the same category, depending on the finer scale quality of the surroundings (urban vs. suburban).

On top of the role of location, the hedonic price analysis also revealed that, in addition to the size of the hotel and the number of non-ecosystem amenities offered to the guests, room prices were generally positively correlated to the possibility of enjoying the beauty of the landscape (in Costa Esmeralda) and recreation on the beach (proximity to the beach, in all three sites). Interestingly, our results revealed that in the more suburban locations (Costa Esmeralda and Chachalacas), the prices were similar to those hotels from the more urbanized location (Boca del Río) as long as hotels had both direct access to the beach and an ocean view. In brief, in our three study sites, if we assumed a 100\% occupancy rate in the hotels per day (which occurs during high-season vacationing periods), the approximate extra annual income in Boca del Río, Costa Esmeralda, and Chachalacas would be $\$ 36,377, \$ 43,652$, and $\$ 8148$ USD for proximity to the beach and $\$ 208,927, \$ 77,373$, and $\$ 45,184$ USD for the ocean view, respectively. These results highlight the relevance of these attributes for hotel pricing, independently of the location, which supports previous studies such as those by Liu et al. [45], Hamilton [20], Rigall-I-Torrent et al. [29], Hunt et al. [46], Ergin et al. [33], and Rangel-Buitrago et al. [34], who also observed that proximity to natural landscapes such as beaches, parks, water bodies, and wetlands increased property value and hotel prices. 
The relevance of proximity to recreation on the beach and access to coastal aesthetics has led to an urban growth that initially occurs along the coastlines, which is followed by the subsequent inland expansion [18]. In our study areas, we did not analyze the loss of other ecosystem services potentially affected by the environmental degradation caused by the construction of hotels. The only services we studied (scenic beauty and recreation) have not been affected in the vicinities of the hotels we studied. However, it is expected that as touristic developments grow, the aesthetics and proximity to recreation on the beach will be altered, and the natural elements that were initially of interest to tourists will either be lost or diminished [18,43]. For future analysis, quality of scenic view (from top grade to poor scenery) must be analyzed to understand the most important physical and human parameters of beach quality. For example, Williams et al. [47] observed that the finest coastal scenery was found in remote natural areas whilst urban scored the poorest classifications for these parameters.

Given the likelihood that tourism will become one of the largest sectors in the world trade economy, the potential contribution of tourism to sustainable development is substantial [11], and thus needs to be considered carefully. Indeed, human encroachment on the coast is a global phenomenon [48], with population densities three times higher than inland [49], and it has generated a strong and intense degradation and loss of coastal ecosystems in recent decades. This highlights the dilemma of how to promote the very socio-economically relevant activities of sun, sea, and sand tourism, while also maintaining additional ecosystem services, such as coastal protection, which are important both for touristic activities and for society in general. When planning and management support the conservation and proper use of natural ecosystems and different ecosystem services, the sustainable development of the coasts is promoted. In the next section, we discuss different alternatives that could be helpful in this regard, and that would assist with the protection, management, and development of coastal areas $[31,50]$.

- Density of hotels-The sustainable development of the coasts needs to include the conservation of shoreline dynamics and biodiversity, while socio-economic growth is promoted. Thus, it is highly relevant to consider the consequences that different densities of construction have on shoreline dynamics, landscape aesthetics, and beach recreation. In our study sites, the lower hotel densities in Costa Esmeralda and Chachalacas and a higher percentage of natural elements in the landscape allow the possibility for better planning. Thus, a sustainable socio-economic growth of these coastal zones (and others) should maintain the dynamic functioning of the beaches and dunes, while preserving ecosystem services such as landscape aesthetics, recreation, and shoreline protection. In this sense, recent studies have demonstrated that low-density tourism can be compatible with the preservation of beach and dune vegetation [51]. Ideally, an optimum density of hotels and infrastructure must be found for each location so that the appreciation of the landscape aesthetics is available while economic benefits are still generated. However, a controlled development does not imply that all coasts should be developed, as it is necessary to leave space for nature conservation.

- Proximity to the ocean-Our results and those of other authors (for example, [14,44] Liu et al., 2010, Onofri and Nunes, 2013) indicate that proximity to the ocean is an element of great value because of the implied proximity to the recreational activities offered on the beaches. However, the presence of urban and touristic development on the coast generates two important problems. Firstly, the combination of increasing sea levels with coastal urbanization leads to the phenomenon known as coastal squeeze [35]. When coastal squeeze occurs, the infrastructure impedes the inland migration of the natural ecosystems as a response to rising sea levels. In this way, these systems are threatened and the risk of loss is very high [35]. Secondly, when infrastructure is located too close to the ocean, the population is at increasing risk. In fact, extreme hydro-meteorological events such as hurricanes, cyclones, and tropical storms are considered amongst the most damaging disasters which, from 1900 to 2017, have cost over 1200 billion USD in property damage, 1,000,000 human lives, and affected more than 1 billion people (EM-DAT 2017). 
In this sense, in previous studies performed in South Carolina, Pompe and Rinehart [25] found that wide beaches are more valued for their protective function against storms than for their recreational value. Likewise, erosion along the length of the beach can cause economic losses, as demonstrated by Parsons and Powel [52] on the coast of Delaware, where the value of properties closest to the coastline declined due to erosion of the beach. More recently, following the impact of Superstorm Sandy, and given the stark contrasts between coastal areas in New Jersey that were and were not protected by dunes, construction of coastal artificial dunes along the New Jersey coast is now mandatory [53]. Furthermore, different studies have demonstrated that natural ecosystems help protect the coasts against flooding and erosion after the impact of storms [54]. Therefore, to achieve a sustainable coastal tourism, it is important to consider a re-analysis of the optimal distance from the beach for the construction of hotels and cities, in such a way that neither landscape aesthetics nor coastal protection is compromised. This is particularly necessary in countries like Mexico where every year, all the coasts are exposed to hurricane hits.

\section{Study Caveats}

We are fully aware that our surveys are not recent (ten years) and this can potentially generate some problems. First, because of inflation, prices have certainly varied. To solve this issue, we adjusted prices over the years, considering inflation rates. Secondly, it is possible that tourist preferences may have changed significantly over time. Certainly, enjoyment and relaxation based on sun, sea, and sand still remain the basis of coastal tourism, although tourists may also seek now additional conditions such as marine and coastal recreational activities, excellent facilities, and cultural attributes, among others. Although this is true, tourist development in the study areas only has changed in terms of a relatively larger number of hotels and restaurants, but the general conditions have remained unchanged. The databases from the Ministry of Tourism [55] show that from 2007 to 2016, the number of hotels increased by $24 \%$ in Boca del Río, 17 in Costa Esmeralda, and $60 \%$ in Chachalacas. Nevertheless, there are no new marinas; cultural assets (nearby pyramids) are still being visited by tourists, and the dunes on Chachalacas are still being enjoyed by tourists. In this sense, it was interesting to note that the extensive urban growth observed in Chachalacas occurred along the coast, with all the new hotels located at the beach (Martínez et al., 2017). This is evidence of the ongoing preference for an ocean view and the proximity to the beach.

\section{Conclusions}

An ocean view and proximity to the beach are environmental amenities for which hotels charge and tourists are willing to pay. This is how sea, sand, and sun tourism has grown in many countries, including Mexico [2], and the immediate benefits are clear. Indeed, coastal development and tourism are strongly dependent on the surrounding environment from which tourists find recreation and enjoyment of the scenery, yielding millions of dollars in profits [56]. Thus, if coastal countries want to increase their tourist-derived economic profits, it is critical that coastal development takes place in optimal and sustainable conditions: that tourists receive what they seek, and that the environment and coastal ecosystems are preserved, so that the tourist industry is sustained and, additionally, the vulnerability and flood risk in coastal populations is reduced.

Acknowledgments: GMG is grateful to Robert Costanza for his advice and hospitality at the University of Vermont, USA. Thanks are also due to K. MacMillan for his help translating the manuscript into English. We thank the reviewers for their valuable comments that helped improve the paper. This study was funded by FOMIX-Veracruz CONACYT (37009).

Author Contributions: Gabriela Mendoza-González and M. Luisa Martínez conceived the idea, designed the work and mainly wrote the paper. Gabriela Mendoza-González, acquired the data. Octavio Perez-Maqueo, Roger Guevara and Alan Howard analyzed and interpreted the data and results. Cristina Garza-Lagler, contributed to the analysis of data and participated with proof-reading the manuscript.

Conflicts of Interest: The authors declare no conflict of interest. 


\section{Appendix A}

INDAGINE

$01 / 09 / 2008$

\begin{tabular}{|c|c|c|c|}
\hline Clave & Descripción & Tipo & Respuestas \\
\hline 1 & Nombre del Hotel & Abierta & \\
\hline 2 & Ubicación geográfica & Tabular & "Latitud","Longitud" \\
\hline 3 & Seleccionar categoría del Hotel & Cerrada Unica & $\begin{array}{l}\text { "Sin categoria","Casa de } \\
\text { huespedes", "Casa de } \\
\text { descanso","Bungalow","1E","2E","3E","4E } \\
\text { turismo" }\end{array}$ \\
\hline 4 & Ubicación del Hotel & Cerrada Unica & "Sobre la playa","Atravezando la carretera" \\
\hline 5 & Tipo de habitaciones & $\begin{array}{l}\text { Cerrada } \\
\text { Múltiple }\end{array}$ & "Sencilla","KS","Doble","Triple","Cuatruple \\
\hline 6 & Precio y caractéristicas de las habitaciones & Tabular & $\begin{array}{l}\text { "Tipo de Habitacion","'No. de } \\
\text { habitaciones","No. De } \\
\text { camas","Capacidad (pers)","Vista al } \\
\text { mar","Precio" }\end{array}$ \\
\hline 7 & Número total de habitaciones & Numérica & \\
\hline 8 & Alberca & Dicotómica & "Si","No" \\
\hline 9 & Otros servicios & $\begin{array}{l}\text { Cerrada } \\
\text { Múltiple }\end{array}$ & $\begin{array}{l}\text { "Ventiladores","Clima", "TV","Ecoturismo", } \\
\text { verde","Acceso a } \\
\text { playa","Camping","Balneario","'Sala de } \\
\text { eventos","'Gimnasio","Bar","Spa","Ninguno }\end{array}$ \\
\hline
\end{tabular}

SISTEMA DE EVALUACIÓN DE ENCUESTAS

\section{References}

1. Moreno-Casasola, P. Entornos Veracruzanos: La Costa de la Mancha; Instituto de Ecología, A.C.: Xalapa, Mexico, 2006; p. 483.

2. Nordstrom, K.F. Beaches and Dunes of Developed Coast; Cambridge University Press: Cambridge, UK, 2008.

3. United Nations World Tourism Organization (UNWTO). Tourism Highlights. 2016. Available online: http:/ / www.e-unwto.org/doi/pdf/10.18111/9789284418145 (accessed on 27 June 2017). 
4. Jedrzejczak, M.F. The modern tourist's perception of the beach: Is the sandy beach a place of conflict between tourism and biodiversity? In Managing the Baltic Sea. Coastline Reports; Schernewski, G., Löser, N., Eds.; EUCC: Berlin, Germany, 2004; pp. 109-119.

5. Ley-Vega, C.; Gallego-Fernández, J.B.; Vidal Pascual, C. Manual de Restauración de Dunas Costeras; Gobierno de España, Ministerio de Medio Ambiente: Madrid, Spain, 2007; p. 251.

6. Martínez, M.L.; Moreno-Casasola, P.; Espejel, I.; Jiménez-Orocio, O.; Infante-Mata, D.; Rodríguez-Revelo, N. Diagnóstico de las Dunas Costeras de México; CONAFOR: Guadalajara, Mexico, 2014; p. 350.

7. Propín-Frejomil, E.; Sánchez-Crispín, A.; Alvarado Sizzo, I. Niveles de selectividad territorial de los destinos turísticos en México. Cuad. Tur. 2017, 39, 495-520. [CrossRef]

8. SECTUR. Sexto Informe de Labores; Secretaría de Turismo: Mexico City, Mexico, 2013.

9. Martínez, M.L. Las Playas y Las Dunas Costeras. Un Hogar en Movimiento; Colección La Ciencia Para Todos; Fondo De Cultura Economica USA: San Diego, CA, USA, 2009; p. 198.

10. Everard, M.; Jones, L.; Watts, B. Have we neglected the societal importance of sand dunes? An ecosystem services perspective. Aquat. Conserv. Mar. Freshw. Ecosyst. 2010, 20, 476-487. [CrossRef]

11. Hunter, C. Sustainable tourism as an adaptive paradigm. Ann. Tour. Res. 1997, 24, 850-867. [CrossRef]

12. Williams, A.T. Definitions and typologies of coastal tourism beach destinations. In Disappearing Destinations: Climate Change and Future Challenges for Coastal Tourism; Jones, A.L., Phillips, M.R., Eds.; CABI: Oxford, UK, 2011; pp. 47-66.

13. George, B.P.; Henthorne, T.L.; Williams, A.J. Attraction diversity index: The concept, measure, and its relation with tourism destination competitiveness. Tur. Estud. Prát. 2017, 5, 9-29.

14. Onofri, L.; Nunes, P.A.L.D. Beach 'lovers' and 'greens': A worldwide empirical analysis of coastal tourism. Ecol. Econ. 2013, 88, 49-56. [CrossRef]

15. Vargas-Martínez, E.E.; López-Moreda, L.J.; Martínez-Cervantes, R.S.M. La dimensión ambiental en las preferencias de consumo del turista. Caso Cancún. Rev. Adm. Unim. 2014, 12, 42-58. [CrossRef]

16. Pérez-Verdín, G.; Sanjurjo-Rivera, E.; Galicia, L.; Hernandez-Diaz, J.C.; Hernandez-Trejo, V.; Marquez-Linares, M.A. Economic valuation of ecosystem services in Mexico: Current status and trends. Ecosyst. Serv. 2016, 21, 6-19. [CrossRef]

17. Jiménez-Orocio, O.; Espejel, I.; Martínez, M.L. La investigación científica sobre dunas costeras de México: Origen, evolución y retos. Rev. Mex. Biodivers. 2015, 86, 486-507. [CrossRef]

18. Mendoza-González, G.; Martínez, M.L.; Lithgow, D.; Pérez-Maqueo, O.; Simonin, P. Land use change and its effects on the value of ecosystem services along the coast of the Gulf of Mexico. Ecol. Econ. 2012, 82, $23-32$. [CrossRef]

19. Rosen, S. Hedonic prices and implicit markets: Product differentiation in pure competition. J. Political Econ. 1974, 82, 34-35. [CrossRef]

20. Hamilton, J.M. Coastal landscape and the hedonic price of accommodation. Ecol. Econ. 2007, 62, $594-602$. [CrossRef]

21. Fleischer, A.; Tchetchik, A. Does rural tourism benefit from agriculture? Tour. Manag. 2005, 26, $493-501$. [CrossRef]

22. Mardones, C. Impacto de la percepción de la calidad del aire sobre el precio de las viviendas en Concepción-Talcahuano, Chile. Cuad. Econ. 2006, 43, 301-329.

23. Murty, M.N.; Gulati, S.C.; Banerjee, A. Hedonic Property Prices and Valuation of Benefits from Reducing Urban Air Pollution in India; Institute of Economic Growth, Delhi University Enclave: Delhi, India, 2003.

24. Tolun, G.; Ergenekon, L.S.; Hocaoglu, S.M.; Donertas, A.S.; Cokacar, T.; Husrevoglu, S.; Beken, C.P.; Baban, A. Socioeconomic response to water quality: A first experience in science and policy integration for the Izmit Bay coastal system. Ecol. Soc. 2012, 17, 40.

25. Pompe, J.J.; Rinehart, J.R. Beach quality and the enhancement of recreational property values. J. Leis. Res. 1995, 27, 143-154. [CrossRef]

26. Boyle, M.A.; Kiel, K.A. A Survey of House Price Hedonic Studies of the Impact of Environmental Externalities. J. Real Estate Lit. 2001, 9, 117-144.

27. Costanza, R.; Wilson, M.; Troy, A.; Voinov, A.; Liu, S.; D'Agostino, J. The Value of New Jersey's Ecosystem Services and Natural Capital; Gund Institute for Ecological Economics, University of Vermont: Burlington, VT, USA, 2006; p. 177. 
28. Vanslembrouch, I.; Huylenbroeck, G.V.; Meensel, J.V. Impact of Agriculture on Rural Tourism: A Hedonic Pricing Approach. J. Agric. Econ. 2005, 56, 17-30. [CrossRef]

29. Rigall-I-Torrent, R.; Fluvia, M.; Ballester, R.; Saló, A.; Ariza, E.; Espinet, J.-M. The effects of beach characteristics and location with respect to hotel prices. Tour. Manag. 2011, 32, 1150-1158. [CrossRef]

30. Latinopoulos, D. Using a spatial hedonic analysis to evaluate the effect of sea view on hotel prices. Tour. Manag. 2018, 65, 87-99. [CrossRef]

31. Hulten, C.R. Price Hedonics: A Critical Review. Federal Reserve Bank of New York. Econ. Policy Rev. 2003, 9 , 5-15.

32. Rangel-Buitrago, N.; Anfuso, G.; Correa, I.; Ergin, A.; Williams, A.T. Assessing and managing scenery of the Caribbean Coast of Colombia. Tour. Manag. 2013, 35, 41-58. [CrossRef]

33. Ergin, A.; Williams, A.T.; Micallef, A. Coastal scenery: Appreciation and evaluation. J. Coast. Res. 2006, 22, 958-964. [CrossRef]

34. Lloret, A.; Domenge, R.; Saz, I.; Carus, L.; Rivera, M.; Muñoz, C. Economic Incentives to Adopt Sustainable Practices in the Tourism Industry in Mexico. Presented at the Annual Meeting of the BALAS Annual Conference, ESADE, Barcelona, Spain, 24 March 2010.

35. Martínez, M.L.; Mendoza-González, G.; Silva-Casarín, R.; Mendoza-Baldwins, E. Land use changes and sea level rise may induce a "coastal squeeze" on the coasts of Veracruz, Mexico. Glob. Environ. Chang. 2014, 29, 180-188. [CrossRef]

36. Comisión Nacional para el Conocimiento y Uso de la Biodiversidad (CONABIO). Capital Natural y Bienestar Social; CONABIO: Mexico City, Mexico, 2006; pp. 49-54.

37. Wojtarowski, L.A. Educación ambiental en el sector turístico: El caso de un grupo de hoteleros de Playa de Chachalacas, El colegio de Veracruz (COLVER). Ph.D. Thesis, Universidad Veracruzana, Xalapa, Mexico, 4 September 2015.

38. Marsh, C. The Survey Method. The Contribution of Surveys to Sociological Explanation; Allen and Unwin: London, UK, 1982; 185p.

39. De Vaus, D.A. Surveys in Social Research, 2nd ed.; Unwin Hyman: London, UK, 1990; 368p.

40. Miller, C.R. Handbook of Research Design and Social Measurement, 5th ed.; Sage Publications: London, UK, $1991 ; 808$ p.

41. Lugan, J.C. Elementos Para el Análisis de los Sistemas Sociales; Fondo de Cultura Economica: Mexico City, Mexico, 1995; 271p.

42. INEGI, Instituto Nacional de Estadística y Geografía. Calculadora de Inflación. Available online: http:/ / www.inegi.org.mx/sistemas/indiceprecios/calculadorainflacion.aspx (accessed on 29 March 2018).

43. BANXICO, Banco de Mexico. Available online: http://www.banxico.org.mx (accessed on 29 March 2018).

44. SECTUR; CONACYCT; CESTUR. Análisis de Mejores Prácticas y Generación de Una Metodología Para la Clasificación Hotelera en México; Factor Delta: Mexico City, Mexico, 2012; p. 284.

45. Liu, S.; Costanza, R.; Troy, A.; D’Aagostino, J.; Mates, W. Valuing New Jersey's ecosystem services and natural capital: A spatially explicit benefit transfer approach. Environ. Manag. 2010, 45, 1271-1285. [CrossRef] [PubMed]

46. Hunt, L.M.; Boxall, P.; Englin, J.; Haider, W. Remote tourism and forest management: A spatial hedonic analysis. Ecol. Econ. 2005, 53, 101-113. [CrossRef]

47. Williams, A.T.; Micallef, A.; Anfuso, G.; Gallego-Fernández, J.B. Andalusia, Spain: An Assessment of Coastal Scenary. Landsc. Res. 2012, 37, 327-349. [CrossRef]

48. McGranahan, G.; Balk, D.; Anderson, B. The rising tide: Assessing the risks of climate change and human settlements in low elevation coastal zones. Environ. Urban. 2007, 19, 17-37. [CrossRef]

49. Barbier, E.B.; Koch, E.W.; Silliman, B.R.; Hacker, S.D.; Wolanski, E.; Primavera, J.; Granek, E.F.; Polasky, S.; Aswani, S.; Cramer, L.A.; et al. Coastal ecosystem-based management with nonlinear ecological functions and values. Science 2008, 319, 321-323. [CrossRef] [PubMed]

50. Silva, R.; Martínez, M.L.; Odériz, I.; Mendoza, E.; Feagin, R.A. The reduction of dune face erosion by vegetation. Coast. Eng. 2016, 109, 53-62. [CrossRef]

51. Pérez-Maqueo, O.; Martínez, M.L.; Cóscatl, R. Is the conservation of beach and dune vegetation compatible with tourism? Tour. Manag. 2017, 58, 175-183. [CrossRef]

52. Parsons, G.R.; Powell, M. Measuring the cost of beach retreat. Coast. Manag. 2001, 29, 91-103.

53. Charbonneau, B.R. A review of dunes in today's society. Coast. Manag. 2015, 43, 465-470. [CrossRef] 
54. Salgado, K.M.; Martínez, M.L. Is ecosystem-based coastal defence a realistic alternative? Exploring the evidence. J. Coast. Conserv. 2017, 21, 837-848. [CrossRef]

55. Ministry of Tourism. Available online: http://www.veracruz.gob.mx/finanzas/anuario-estadistico (accessed on 1 February 2018).

56. Clark, J.R. Coastal Zone Management Handbook; CRC Press/Lewis Publishers: Boca Raton, FL, USA, 1996.

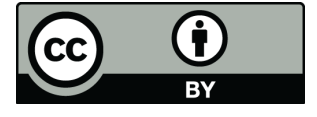

(C) 2018 by the authors. Licensee MDPI, Basel, Switzerland. This article is an open access article distributed under the terms and conditions of the Creative Commons Attribution (CC BY) license (http://creativecommons.org/licenses/by/4.0/). 